\title{
Perancangan sistem Pembangkit Listrik Pico Hydro Putaran Rendah Menggunakan Turbin Screw
}

\author{
M. Suyanto ${ }^{1}$, Syafriudin ${ }^{2}$, Anas Cahyo Nugroho ${ }^{3}$, Prasetyono Eko $\mathbf{P}^{4}$, Subandi $^{5}$ \\ 1,2,3,4,5 Jurusan Teknik Elektro, Institut Sains \& Teknologi AKPRIND Yogyakarta \\ Jl.Kalisahak No 28 Komplek Balapan Jogjakarta (0274) 563029, Fax. (0274)563847 \\ e-mail: myanto@akprind.ac.id ${ }^{1}$,dien@akprind.ac.id², anascahyonugroho@gmail.com ${ }^{3}$,prastyono@akprind.ac.id ${ }^{4}$, \\ subandi@ akprind.ac.id ${ }^{5}$
}

\begin{abstract}
Abstrak. Kinerja sebuah screw turbine dipengaruhi oleh parameter-parameter yang terkait dalam perancangan screw turbine itu sendiri. Salah satu parameter penting dalam perancangan screw turbine adalah pitch atau jarak periode dari sebuah sudu (blade), sudut kemiringan, putaran dan debit air Kebutuhan akan energi listrik saat ini dirasakan sangatlah penting, baik untuk kebutuhan rumahan, maupun untuk kebutuhan industri yang semakin hari semakin berkembang, sementara unit-unit pembangkit listrik yang ada hampir tidak mengalami peningkatan yang signifikan. Indonesia mempunyai potensi energi terbarukan yang cukup banyak untuk dimanfaatkan salah satunya energi air. Potensi ini belum bisa dimanfaatkan secara optimal karena keterbatasan teknologi turbin dalam memanfaatkan energinya. Untuk head dan debit yang sedang hingga tinggi saat ini masih mengandalkan turbin Pelton, Francis, Kaplan, dan Crossflow. Sedangkan untuk head yang rendah masih sulit untuk dikembangkan, padahal di Indonesia mempunyai potensi yang sangat besar. Dalam pengujian PLTPH menggunakan turbin screw didapatkan hasil tertinggi dengan tegangan 129,2 $\mathrm{V}$ AC dengan arus beban tertinggi hingga 0,65 sedangkan ampere generator sebesar 1,79 Ampere yang mampu digunakan untuk beban hingga $180 \mathrm{~W}$ pada tegangan 75,5 Volt AC pada ketinggian air $80 \mathrm{Cm}$, dan pada keadaan tegangan terendah menghasilkan 80,6 Volt AC dengan ampere beban 0,15 dan Ampere generator sebesar 0,42 Ampere yang dapat dibebani dengan lampu 20 Watt pada ketinggian air $70 \mathrm{Cm}$.
\end{abstract}

Kata Kunci: PLTPH, Turbin Screw, Generator AC.

\section{PENDAHULUAN}

Potensi sumber energi terbarukan di Indonesia meliputi $4,8 \mathrm{KWh} / \mathrm{m}^{2} / \mathrm{hari}$ energi surya, $458 \mathrm{GW}$ biomassa, 3-6 m/s tenaga angin, dan $3 \mathrm{GW}$. Selain itu indonesia juga memiliki sumber energi hidro yang besar dengan total potensial diperkirakan 75.67 GW. Akan tetapi potensi besarnya tidak diimbangi dari energi terbarukan seperti biomassa, panas bumi, energi surya, energi air, energi angin, dan energi lautan relative tinggi, namun tidak digunakan secara signifikan.

Salah satu sumber energi terbarukan yang sangat berpotensi di Indonesia adalah pemanfaatan energi air.[1]. Pembangkit listrik energi terbarukan dengan memanfaatkan energi air bisa dibuat dalam skala besar maupun kecil. Pico Hydro atau yang dimaksud dengan Pembangkit Listrik Tenaga Piko Hidro (PLTPH) adalah suatu pembangkit listrik skala kecil yang menggunakan tenaga air sebagai tenaga penggeraknya seperti, saluran irigasi,

sungai atau air terjun alam dengan cara memanfaatkan tinggi terjunan (head) dan jumlah debit air. Salah satu komponen yang terpenting dalam pembangkit listrik mikrohidro adalah turbin. Banyak jenis turbin yang digunakan dalam pembangkit listrik tenaga mikrohidro, salah satunya adalah turbin screw. Turbin Archimedes screw atau sering juga disebut dengan turbin ulir merupakan teknologi yang sejak zaman kuno telah ditemukan dan diterapkan sebagai pompa, dimana pada konstuksinya terdiri dari satu atau beberapa sudu berbentuk heliks yang terpasang pada poros dan berfungsi sebagai bucket bergerak untuk membawa air ke atas.

Pembangkit listrik pico hydro mengacu pada pembangkit listrik dengan skala di bawah $<5 \mathrm{~kW}$.[2]. Banyak daerah pedesaan di Indonesia yang dekat dengan aliran sungai yang memadai untuk pembangkit listrik pada skala yang demikian. Diharapkan dengan memanfaatkan potensi yang ada di desa-desa tersebut dapat memenuhi kebutuhan energinya sendiri dalam mengantisipasi kenaikan biaya energi atau kesulitan jaringan listrik nasional untuk menjangkaunya. Salah satu sumber energi terbarukan adalah aliran air. Untuk mengkonversi aliran air menjadi energi listrik diperlukan sebuah generator yang terhubung dengan turbin yang disebut dengan Pembangkit Listrik Tenaga Pico Hydro (PLTPH).

\section{METODE PENELITIAN}

Metode yang digunakan dalam penelitian, terdiri dari, melakukan studi kepustakaan sebagai referensi yang berkaitan dengan penelitian yang dilakukan. Mengkaji relevan yang bersesuaian dengan perancangan boost converter pada PLTH pico hydro. Kinerja sebuah screw turbine dipengaruhi oleh parameter-parameter yang terkait dalam perancangan screw turbine itu sendiri. Salah satu parameter penting dalam perancangan screw turbine adalah pitch atau jarak periode dari sebuah sudu (blade), sudut kemiringan, putaran dan debit air.[3].

Blok diagram Gambar 1. Flowchart perancangan alat. 


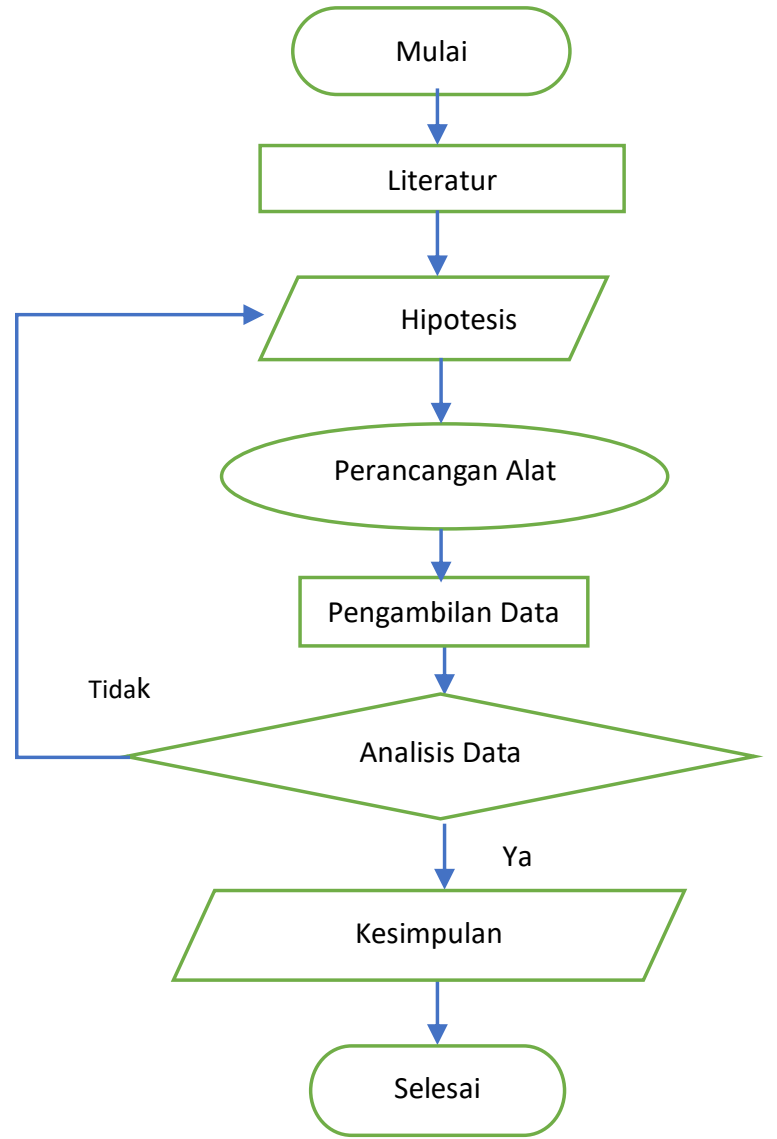

Gambar 1. Flowchart perancangan alat

Kebutuhan akan energi listrik saat ini dirasakan sangatlah penting, baik untuk kebutuhan rumahan, maupun untuk kebutuhan industri yang semakin hari semakin berkembang, sementara unit-unit pembangkit listrik yang ada hampir tidak mengalami peningkatan yang signifikan. Indonesia mempunyai potensi energi terbarukan yang cukup banyak untuk dimanfaatkan salah satunya energi air. Potensi ini belum bisa dimanfaatkan secara optimal karena keterbatasan teknologi turbin dalam memanfaatkan energinya. Perancangan ini didasari atas keterbatasan penyediaan energi listrik di daerah terpencil, padahal sekitar daerah tersebut terdapat sumber energi air yang cukup walaupun mempunyai head yang rendah. Sehingga potensi untuk pembangkit listrik dengan memanfaatkan energi air dengan head rendah perlu dikembangkan. Untuk dapat mengkonversi energi air tersebut diperlukan turbin khusus salah satunya turbin air tipe screw. Prinsip kerja turbin screw ini didasari atas sistem pompa screw yang berfungsi mengangkat air dari sungai menuju permukaan. Turbin screw pada dasarnya merupakan kebalikan dari pompa ulir.

Pembangkit listrik tenaga pico hydro adalah suatu pembangkit yang dapat menghasilkan energi listrik kurang dari $5 \mathrm{~kW}$ dan dapat diklasifikasikan sebagai pembangkit listrik berskala kecil.

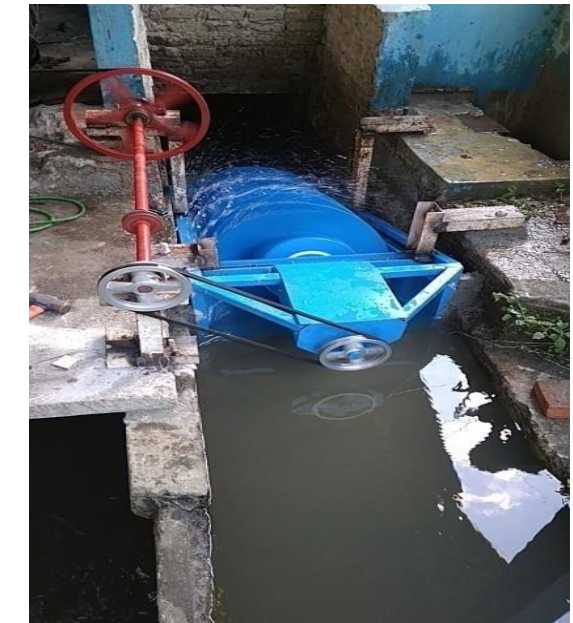

Gambar 2. PLTPH Turbin Screw

Prinsip pembangkitan tenaga air adalah suatu bentuk perubahan tenaga dari tenaga air dengan ketinggian dan debit tertentu menjadi tenaga listrik, dengan menggunakan turbin dan generator. Pembangkit listrik tenaga air skala piko pada prinsipnya memanfaatkan beda ketinggian dan jumlah debit air per detik yang ada pada aliran sungai. Aliran air ini selanjutnya menggerakkan turbin, lalu turbin menggerakkan generator dan generator menghasilkan listrik. Seperti Gambar 2. (Dokumentasi)

\section{Potensi Air}

Air yang mengalir mempunyai energi yang dapat digunakan untuk memutar roda turbin, karena itu pusat - pusat tenaga air dibangun di sungai dan didaerah pegunungan. Pusat tenaga air tersebut dapat dibedakan dalam 2 golongan, yaitu pusat tenaga air tekanan tinggi dan pusat tenaga air tekanan rendah. Aliran air yang jatuh dengan debit Q (m3/s) yang mengenai kincir atau turbin air akan menghasilkan daya sebesar:[4].

$$
P=\rho \cdot Q \cdot g \cdot H
$$

dimana :

$\mathrm{P}=$ Daya $(\mathrm{W})$

$\rho=$ Kerapatan Air $\left(1000 \mathrm{~kg} / \mathrm{m}^{3}\right)$

$\mathrm{Q}=$ Debit air $\left(\mathrm{m}^{3} / \mathrm{s}\right)$

$\mathrm{g}=$ Gravitasi Bumi $\left(\mathrm{m} / \mathrm{s}^{2}\right)$

$\mathrm{H}=$ Ketinggian Jatuh Air (m)

Daya yang dihasilkan generator dapat dihitung menggunakan persamaan berikut:

P out $=$ V.I

Setelah diperoleh daya, dapat diketahui efisiensi dari pembangkit pembangkit listrik tenaga pico hydro sebagai berikut :

$\mathrm{\eta}=\frac{\mathrm{P}_{\text {out }}}{\mathrm{P} \text { in }} 100 \%$ 
dimana $: \eta=$ Efisiensi

$$
\begin{aligned}
& P_{\text {in }}=\text { Daya Kincir }(\mathrm{W}) \\
& P_{\text {out }}=\text { Daya Generator }(\mathrm{W})
\end{aligned}
$$

Untuk menghitung torsi dapat dilakukan dengan persamaan :

$$
\mathrm{T}=\frac{P}{2 \pi \frac{\pi}{60}}
$$

dimana : $\mathrm{n}=$ Putaran $(\mathrm{rpm})$

$$
\begin{aligned}
& \mathrm{T}=\text { Torsi }(\mathrm{Nm}) \\
& \mathrm{P}=\text { Daya Kincir }(\mathrm{W})
\end{aligned}
$$

\section{Karakteristik Turbin Screw}

Sebuah turbin Screw diatur oleh parameter eksternal tertentu (radius luar, panjang, dan kemiringan) dan parameter internal tertentu (jari-jari dalam, jumlah blade, dan pitch of the blade).

Parameter eksternal biasanya ditentukan oleh penempatan ulir dan bahan yang tersedia untuk konstruksi, sedangkan parameter internal bebas dipilih untuk mengoptimalkan kinerja turbin Screw. Dalam hal ini jari-jari dalam dan blade yang memaksimalkan putaran sirip ulir, Parameter pada turbin Screw dapat dilihat pada Gambar 3.[5]

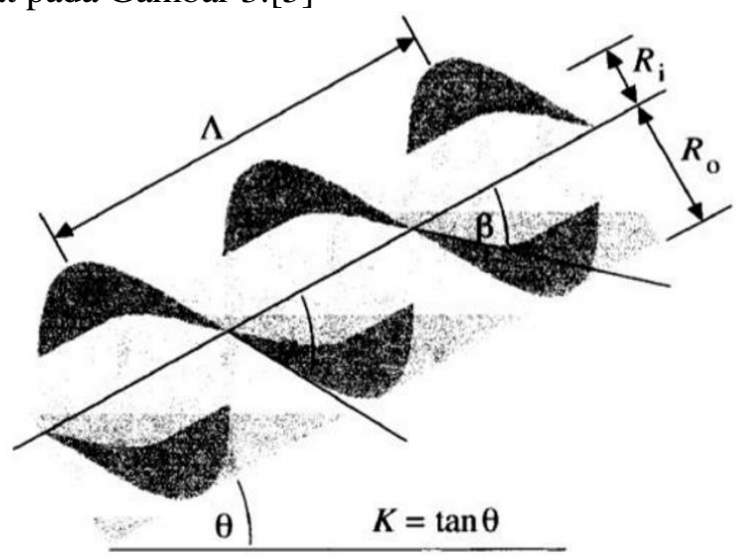

Gambar 3. Bagian Dari Turbin Screw 2 Blade

Parameter parameter pada turbin ulir yaitu:

$R_{0}=$ Radius silinder turbin luar $(m)$

$L=$ Panjang total turbin ulir $(m)$

$K=$ Kemiringan urbin

$R i=$ Radius silinder dalam turbin $(m)$

$A=$ Periode pada satu blade

$N=$ Jumlah blade terdiri 1,2 , atau 3

Ketinggian air

Ketinggian air (head) yang digunakan dalam penilaian ini pada gambar 4. (581/info@ nickbard.co.uk)

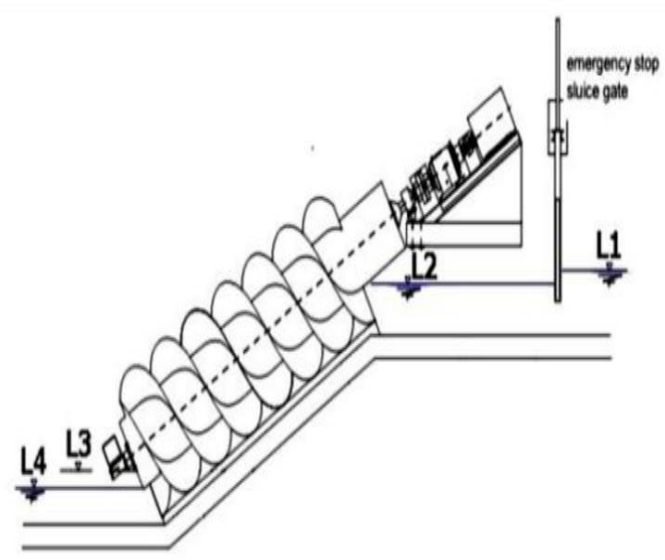

Gambar 4. Menentukan Tingkat Ketinggian Air

dimana:

L1 : tinggi permukaan bak pengendap air (m)

L2 : tinggi permukaan masukan air pada turbin (m)

L3 : tinggi permukaan air pada terowongan / tailrace $(\mathrm{m})$

L4 : tinggi permukaan air actual tailrace (m)

Kecepatan Putaran Generator

Semenjak generator dan turbin digabungkan, rata-rata kecepatan putar turbin sama dengan kecepatan putar generator, dinyatakan sebagai:[6].

$$
N_{t}=\frac{60 f}{p}
$$

dimana:

$\mathrm{Nt}=$ kecepatan putaran $(\mathrm{rpm})$

$f \quad=$ frekwensi $(\mathrm{Hz})$

$p \quad=$ jumlah pasang kutub generator

Jadi kecepatan putaran turbin ditentukan oleh kecepatan putaran generator.

Kecepatan spesifik dari turbin dinyatakan sebagai berikut:

$$
N_{S}=\frac{N_{t}^{t} / p}{h^{5 / 4}}
$$

dengan: $N s=$ kecepatan spesifik $(\mathrm{rpm})$

\section{Perancangan Alat}

Pada perancangan dibuat blok diagram yang menggambarkan tentang perancangan PLTPH Turbin Screw dari tahap awal hingga tahap pengujian. Seperti flowcart diatas gambar 5, tahapan pertama perancang adalah mencari studi literatur yang cukup untuk membuat hipotesis dan melakukan perancangan dengan simulasi dari software untuk mendapatkan data yang diinginkan. Setelah mendapatkan data yang diinginkan masuk ketahap selanjutnya membuat laporan dimana didalam laporan terdapat kesimpulan dari perancangan yang penyusun buat. Seperti Gambar 5. Penjelasan dari cara kerja PLTPH menggunakan turbin screw dengan menggunakan generator AC yaitu pertama aliran air 
irigas masuk melewati pintu air kemudian untuk mengatur debit air yang masuk turbin screw maka diataurlah pintu air sesuai debit yang diinginkan saat melakukan percobaan atu pengujian dalam mencari datalalu, turbin screw akan berputar, disini turbin screw berputar dengan putaran 118 rpm kemudian dihubungkan dengan generator AC dengan menggunakan pulley, disini pulley yang tepasang pada pembangkit listrik tenaga pico hydro ini adalah bertingkat yang defungsi meningkatkan putaran turbin sampai generator dengan ukuran yang sesuai dengan perhitungan.[7].

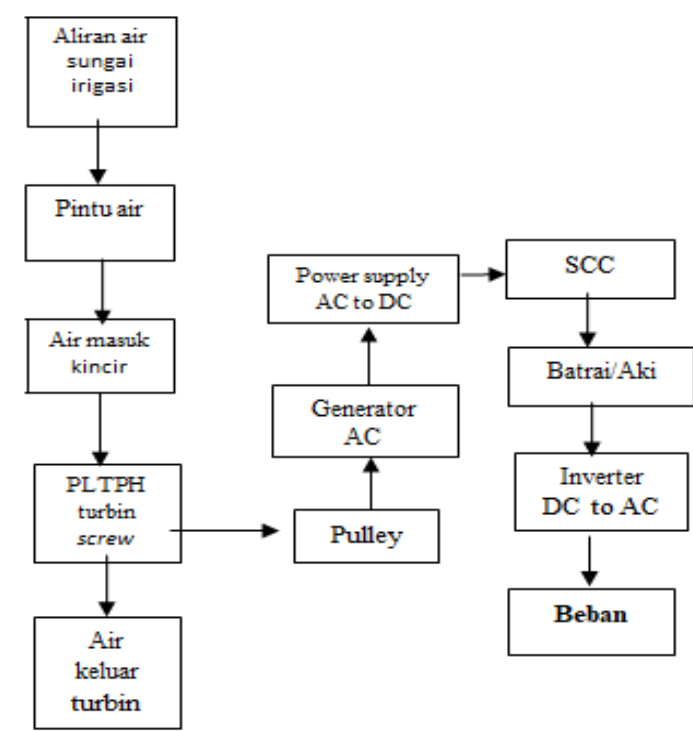

Gambar 5. Diagram alur PLTPH Tubin Screw

Selanjutnya antar pulley dihubungkan dengan menggunakan belt sehingga generator dapat berputar dengan putaran $1085 \mathrm{rpm}$ dan menghasilkan listrik selanjutnya masuk ke power suplly untuk merubah arus AC ke DC dengan output $13 \mathrm{~V}$ DC kemudian masuk ke Solar Charger Controller atau SCC untuk mengatur tegangan yang masuk ke Batrai/AKI dengan baik agar masa pakai Batrai/AKI lebih panjang yaitu disini input terbaik untuk pengisian Batrai/AKI 13,8 Vdc kemudian arus listrik yang dihasilkan dari generator disimpan di Batrai/AKI dengan lama pengisian kurang lebih 16 jam, batrai juga berfungsi agar tegangan lebih stabil selanjutnya keluaran dari Batrai/AKI diubah ke tagangan AC menggunakan inverter dengan kapasitas disini inverter 500 Watt supaya agar dapat digunakan untuk listrik rumah tangga ( pengujian yang sudah dilakukan dengan pembebanan lampu bholam dengan kapasitas 180 watt )

\section{Desain Alat}

Pada pembuatan desain alat digunakan untuk perancangan pembangunan alat, pendesainan ini dilakukan menggunakan software microsoft word yang nantinya akan dijadikan suatu alat untuk pembangkit listrik pada saluran irigasi yang nantinya akan menggunakan Generator AC sebagai penghasil energy listrik untuk pengujian beban menggunakan alat alat seperti bor listrik yang sebelumnya hanya ,encapai 135 $\mathrm{V}$ kemudian menggunakan power suplly agar bisa masuk penyimpanan tegangan listrik ke Batrai kemudian di inverter dengan inverter $500 \mathrm{~W}$.seperti pada gambar 6 .

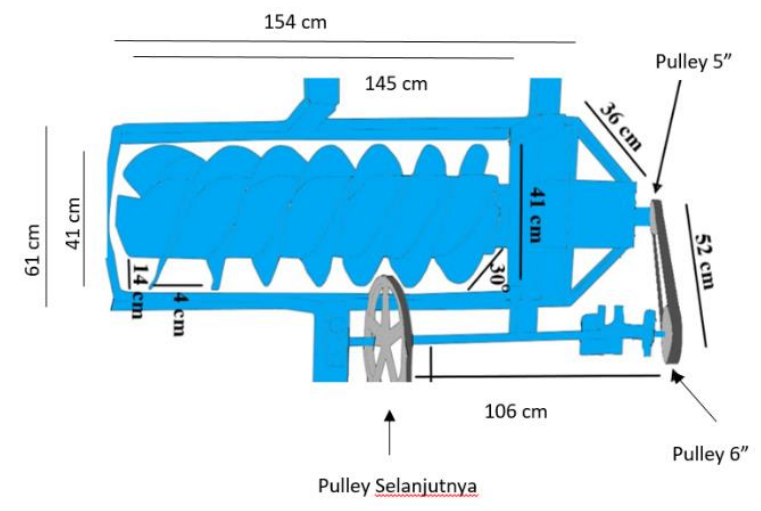

Gambar 6. Desain Turbin Screw

Penjelasan dari cara kerja pemodelan yaitu, Turbin pada penelitian ini berbentuk ulir atau screw yang dapat diletakan pada aliran sungai atau aliran irigasi yang merupakan pengerak mula dan menghasilkan energy listrik, Turbin screw dibuat miring antara head atas dan bawah agar didapatkan tekanan air yang lebih besar. Pada pengujian kali ini digunakan turbin screw dengan 3 buah blade yang diharapkan akan menambah rpm pada screw agar putaran maksimal , Seperti gambar 7. (Dokumentasi)

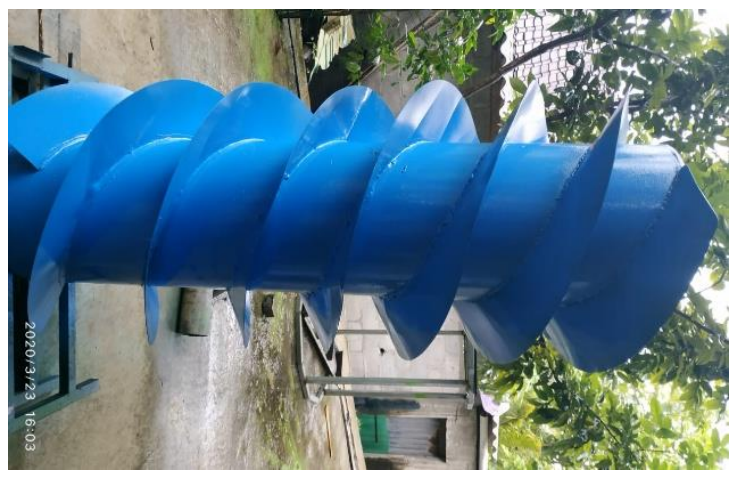

Gambar 7. Turbin Screw

\section{Kerangka Turbin Screw}

Kerangka atau frame pada turbin screw ini berguna untuk meletakan turbin pada aliran irigasi yang telah dihitung atara tinggi dan juga panjang screw, Pada frame kincir diletakan selongsong setengah lingkaran yang berguna agar air mengalir kedalam frame semuanya dari kanal sungai dan menggerakan screw agar bergerak, Seperti gambar 8. (Dokumentasi) 


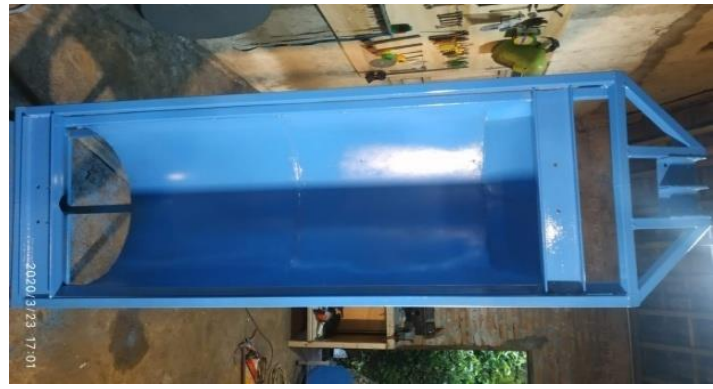

Gambar 8. Frame Atau Rangka

Pertama air dibendung dengan menggunakan pintu air agar mendapatkan daya dorong air untuk awal pemutaran turbin selanjutnya pintu air dibuka dan menabrak bagian sirip - sirip kincir yang telah dirancang dengan sudut $30^{\circ}$ dan memutar turbin dengan kecepatan awal ( sebelum terhubung pulley) sebesar 150-170 rpm tergantung dari debit air yang selanjutna kincir akan dihubungkan ke generator dengan menggunakan pulley bertingkat yaitu awal kincir menggunakan pulley 3" dihubung dengan pulley 6" dan diterukan ke pulley 14" dengan 3" dan diteruskan lagi ke pulley 18" yang nantinya pada generator dipasang pulley 3" sehingga diharapkan rpm akan meningkat 10x yaitu sebesar 1500 rpm sebelum dihubungkan generator.

Setelah dihubungkan pada generator terjadi penurunan rpm dikarenakan kincir kurang torsi yang yang menyebabkan rpm akhir pada generator sebesar $1085 \mathrm{rpm}$, Generator AC disisni hanya menghasilkan tegangan $135 \mathrm{~V}$ kemudian digunakan power supllay untuk mengubah arus AC ke DC agar bisa tertapung energy listrik ke Batrai/AKI dan nantinya akan dihubungkan pada inverter 500w untuk merubah lagi dari arus DC ke AC agar dapat digunakan pada rumah tangga.

\section{HASIL DAN PEMBAHASAN}

Penjelasan dari cara kerja PLTPH menggunakan turbin screw dengan menggunakan generator AC yaitu pertama aliran air irigas masuk melewati pintu air kemudian untuk mengatur debit air yang masuk turbin screw maka diataurlah pintu air sesuai debit yang diinginkan saat melakukan percobaan atu pengujian dalam mencari datalalu, turbin screw akan berputar ,disini turbin screw berputar dengan putaran $118 \mathrm{rpm}$ kemudian dihubungkan dengan generator AC dengan menggunakan pulley, disini pulley yang tepasang pada pembangkit listrik tenaga pico hydro ini adalah bertingkat yang defungsi meningkatkan putaran turbin sampai generator dengan ukuran yang sesuai dengan perhitungan,

Selanjutnya antar pulley dihubung-kan dengan menggunakan belt sehingga generator dapat berputar dengan putaran $1085 \mathrm{rpm}$ dan menghasilkan listrik selanjutnya masuk ke power suplly untuk merubah arus AC ke DC dengan output $13 \mathrm{~V}$ DC, kemudian masuk ke Solar Charger Controller atau SCC untuk mengatur tegangan yang masuk ke Baterai.

\section{Analisis Ketinggian Tegangan Terhadap Putaran Generator}

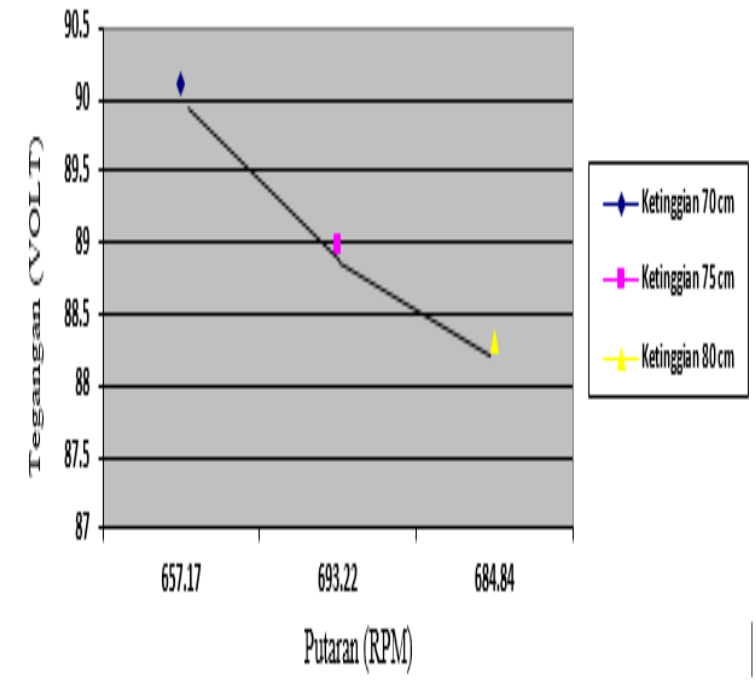

Gambar 9. Grafik Nilai Rata-rata Ketiga Ketinggian

Supaya masa pakai lebih panjang yaitu disini input terbaik untuk pengisian Batrai/AKI 13,8 Vdc kemudian arus listrik yang dihasilkan dari generator disimpan di Baterai/AKI dengan lama pengisian kurang lebih 16 jam, batrai juga berfungsi agar tegangan lebih stabil selanjutnya keluaran dari Batrai/AKI diubah ke tagangan AC menggunakan inverter dengan kapasitas disini inverter 500 Watt supaya agar dapat digunakan untuk listrik rumah tangga ( pengujian yang sudah dilakukan dengan pembebanan lampu bholam dengan kapasitas 180 watt ).

Pada grafik diatas bisa disimpulakan bahwa setiap ketinggian rata-rata dari percobaan mulai dari 70 $\mathrm{Cm}, 75 \mathrm{Cm}$ dan $80 \mathrm{Cm}$ terhadap tegangan generator dan putaran generator bahwa paling efisien adalah pada ketinggian $80 \mathrm{Cm}$ dikarenakan pada ketinggian debit air ini paling maxsimum.

\section{Analisis Daya Beban Terhadap Tegangan Generator}

Diketahui bahwa pada percobaan menggunakan beban dengan lampu bohlam berbagai ukuran sehingga dapat mengetahui tegangan yang ada pada generator, berikut grafik perbandingan daya terhadap Daya beban dengan tegangan generator pada gambar 10 . 


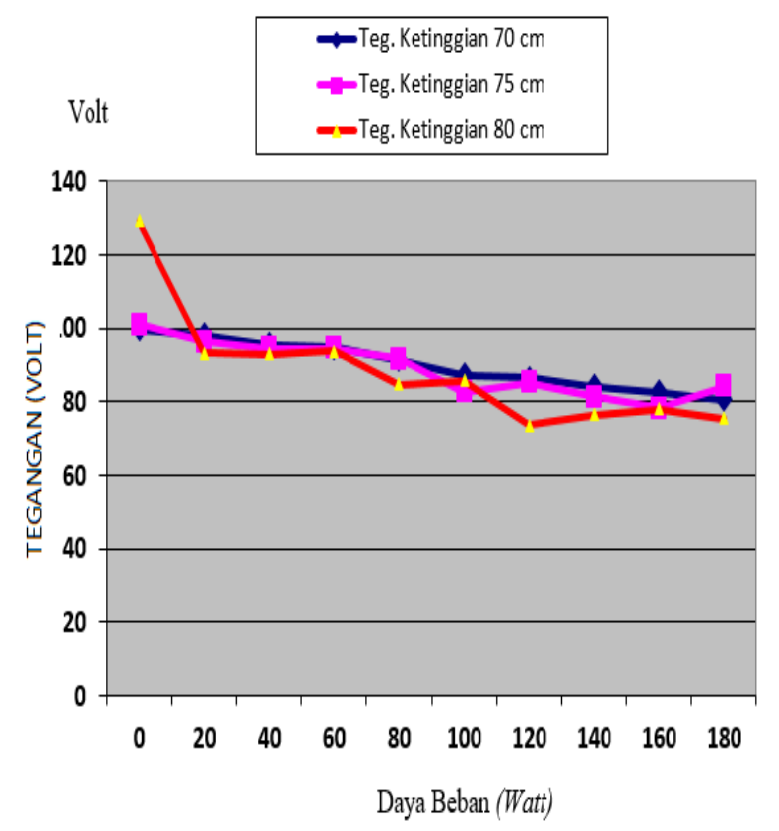

Gambar 10. Grafik Daya Beban dengan Tegangan Generator

\section{Analisis Daya Beban Terhadap Arus Generator}

Diketahui bahwa pada percobaan menggunakan beban dengan lampu bohlam berbagai ukuran sehingga dapat mengetahui arus yang mengalir ada pada generator, berikut grafik perbandingan daya terhadap Daya beban dengan tegangan generator pada gambar 11 .

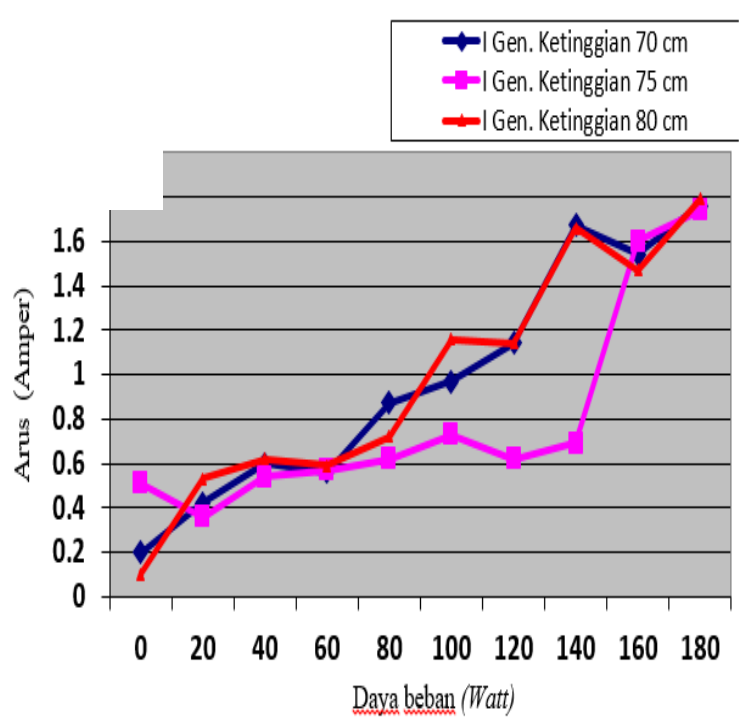

Gambar 11. Grafik Daya Beban dengan Arus Generator

Dari hasil pengujian pembangkit listrik tenaga air menggunakan turbin ulir diketahui bahwa nilai efisien turbin dipengaruhi oleh kemiringan kincir turbin, dalam percobaan menggunakan kemiringan $30^{\circ}$, dengan ketinggian air dengan 3 level yaitu: 70, 75, dan $80 \mathrm{~cm}$, untuk menegetahui kecepatan putaran kincir terhadap tiap level air.

Dalam percobaan digunakan power suplly sebgai pengubah arus AC ke DC agar listrik yang dihasilkan bisa disimpan dibatrai, dipasang Solar Charge Control sebagai penyetabil tegangan pada pengecasan batrai sebagai pengaman dari over charge, semakin tinggi rpm pada generator maka semakin besar tegangan yang dihasilkan generator AC.

Besarnya beban terpasang, akan mempengaruhi arus beban $\mathrm{AC}$ dan mempengaruhi arus pada generator AC, semakin besar beban yang dipasang maka besar arus generator DC hingga 1,79 ampere yang dapat dibebani dengan 180 watt,

Generator Ac diketahui memiliki tingkat efektifitas yang kurang bagus dibandingna dengan generator DC dikarenakan generator AC disini hanya mengeluarkan tegangan $130 \mathrm{v}$ dari yang harusnya bisa $220 \mathrm{~V}$ maka dari itu dibutuhkan power supply agar bisa masuk ke Batrai/AKI sehingga bisa stabil.

\section{Analisis Beban Terhadap Putaran Generator}

Percobaan menggunakan beban dengan lampu pijar, berbagai ukuran sehingga dapat mengetahui tegangan generator, gambar grafik perbandingan daya terhadap beban dengan tegangan generator pada gambar 12.

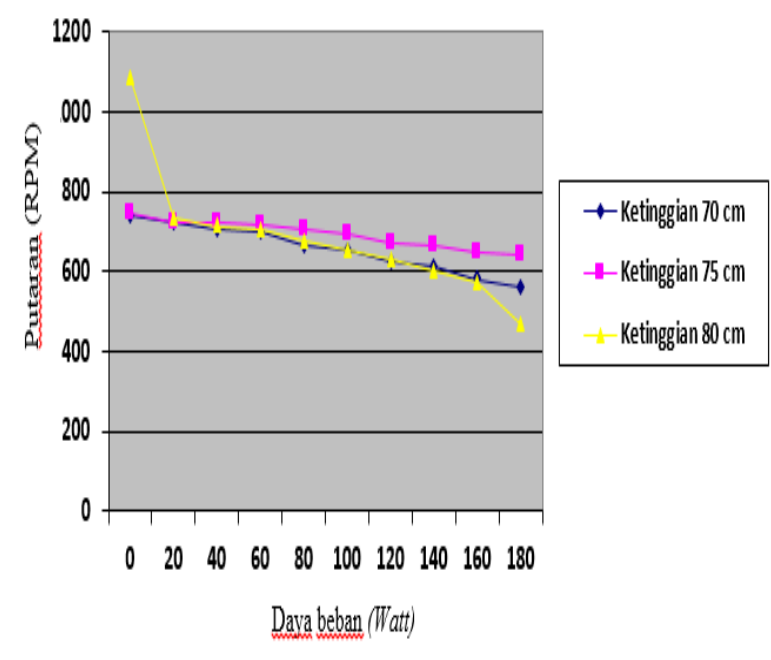

Gambar 12. Grafik Daya Beban Terhadap Putaran Generator

Pada grafik diatas bisa disimpukan semakin banyak beban yang digunakan maka semakin lambat putaran generator,dikarenakan beban semakin menambah mengakibatkan putaran yang dihasikan oleh generator semakin lambat.

\section{SIMPULAN}

Berdasarkan hasil analisis dari pengujian pembangkit listrik tenaga pico hydro dengan menggunakan turbin screw dapat disimpulkan sebagai berikut

1. Pada Perancangan pembangkit listrik tenaga pico hydro dengan turbin screw ini dibuat dengan 7 blade yang diharapkan agar putran turbin yang dihasilkan semakin cepat. 
2. Pada hasil pengujian pertama pada ketinggian 70 $\mathrm{Cm}$ pembangkit listrik pico hydro dengan turbin screw, dengan generator AC didapatkan hasil tertingi yaitu putaran generator $742,4 \mathrm{rpm}$ dengan tegangan generator 99,7 Volt. Dan terendah putaran generator 562,1 rpm dengan tegangan generator 80,6 Volt AC.

3. Pada hasil percobaan kedua pada ketinggian $75 \mathrm{Cm}$ pembangkit listrik pico hydro dengan turbin screw,dengan generator AC didapatkan hasil tertinggi yaitu putaran generator 746,6 rpm dengan tegangan generator 12,24 Volt $\mathrm{AC}$ dan terendah putaran generator $642,1 \mathrm{rpm}$ dengan tegangan 80,6 Volt AC.

4. Pada percobaan ketiga pada ketinggian $80 \mathrm{Cm}$ pembangkit listrik pico hydro dengan turbin screw,dengan generator AC didapatkan hasil maksimal dengan putaran generator 1085,1 rpm dengan tegangan 129,2 Volt AC dan terendah putaran generator $468,2 \mathrm{rpm}$ dengan tegangan 75,5 Volt AC.

\subsection{Saran}

Adapun beberapa saran yang penulis harapkan mampu meningkatkan performa Pembangkit Listrik Pico Hydro dengan turbin screw untuk riset selanjutnya sebagai berikut:

1. Dalam pembuatan turbin harus dilakukan perhitungan yang sangat matang agar tidak terjadi kesalahan mekanisme perancangan.

2. Penggunaan Generator AC pada pembangkit listrik tenaga pico hydro dengan turbin screw sangat tidak efektifitas karena putaran kincir yang dihasilkan tidak dapat memenuhi putaran generator, sebaiknya dengan generator DC tanpa penyimpanan enegi listrik.

\section{DAFTAR PUSTAKA}

[1]. Putra, I. G., Weking, A. I., \& Jasa, L. (2018). Analisa Pengaruh Tekanan Air Terhadap Kinerja PLTMH dengan Menggunakan Turbin Archimedes Screw. Majalah Ilmiah Teknologi Elektro, 17(3), 385-392

[2]. Jamaludin, J. (2018). DEBIT AIR OPTIMUM MODEL SCREW TURBINE PADA PITCH A=1, 2 Ro DAN A= 2 Ro SEBAGAI PENGGERAK GENERATOR LISTRIK. Jurnal Dinamika UMT, 3(1), 9-22.

[3]. Abdulkadir, M. (2017). Pengaruh Sudut Kemiringan Terhadap Kinerja Turbin Ulir. KURVATEK, 2(1), 65-72.

[4]. Saefudin, E., Kristyadi, T., Rifki, M., \& Arifin, S. (2017). Turbin Screw Untuk Pembangkit Listrik Skala Mikrohidro Ramah Lingkungan. Rekayasa Hijau: Jurnal Teknologi Ramah Lingkungan, 1(3)..
[5]. Suharto, B., \& Bekti, E. F. (2016). PEMBUATAN DAN PENGUJIAN TURBIN ULIR DUA SUDU. JURNAL TEKNIK ENERGI, 6(2), 547-550.

[6]. Syahputra, T. M., Syukri, M., \& Sara, I. D. (2017). Rancang Bangun Prototipe Pembangkit Listrik Tenaga Piko Hydro Dengan Menggunakan Turbin Ulir. KITEKTRO: Jurnal Online Teknik Elektro eISSN: 2252-7036 Vol. 2 No,1,1-7.

[7]. M. Suyanto, 2020, Sistem Pengujian Tegangan Boost Converter Pada Pembangkit ListrikTenaga Air (PLTH) Picohydro Kapasitas Rendah, E-ISSN 2621-556X, Journal of Electrical Power Control and Automation Vol.3 No.1, Juni 2020. 